\title{
Mole per Hour
}

National Cancer Institute

\section{Source}

National Cancer Institute. Mole per Hour. NCI Thesaurus. Code C85738.

Moles per hour. 